\title{
Eficacia de la monoterapia con piperacilina- tazobactam en infecciones del área maxilofacial
}

\section{Efficacy of single drug therapy with piperacillin-tazobactam in infections of the maxillofacial area}

\author{
M. Delgado Sánchez1, Y. Herrero Basilio', A. Daura Sáez², A. Modelo Pérez³, E. Fernández Ruiz', \\ J. J. Ruiz Masera', J.C. Casado Morente6, A. Martínez Garrido7, J. Rodas Ibáñez?
}

\begin{abstract}
Resumen: Objetivo: Las infecciones del área maxilofacial representan un motivo habitual de consulta para los cirujanos maxilofaciales, siendo las más frecuentes las de origen dental. Estas infecciones son frecuentemente polimicrobianas, por lo que el objetivo del presente estudio ha sido evaluar la eficacia clínica y seguridad de piperacilina-tazobactam en el tratamiento de las infecciones del área maxilofacial.

Diseño del estudio: Estudio multicéntrico y prospectivo en donde 79 pacientes con infecciones del área maxilofacial recibieron piperacilinatazobactam como tratamiento antibiótico.

Resultados: La evolución clínica de los pacientes fue favorable en un $97,5 \%$ de los pacientes y la eficacia microbiológica obtenida al final del tratamiento fue del $96,2 \%$. Se presentaron reacciones adversas en 5 pacientes (6,3\%): 2 casos de mareo, 2 de dispepsia y un caso de flebitis. En ningún caso se precisó la discontinuación del fármaco.

Conclusiones: La eficacia clínica y microbiológica junto con la escasez de efectos adversos presentados, hace de piperacilina-tazobactam una alternativa eficaz en el manejo de estas infecciones.
\end{abstract}

Palabras clave: infecciones del área maxilofacial - piperacilina-tazobactameficacia clínica- seguridad.

\section{Introducción}

Las infecciones del área maxilofacial constituyen una entidad frecuente en la práctica diaria del cirujano maxilofacial. Cuando se habla de infección maxilofacial se incluye en esta definición una amplia gama

\footnotetext{
1 Servicio de Cirugía Oral y Maxilofacial, Complejo Hospitalario Virgen Macarena, Sevilla. España.

2 Servicio de Cirugía Oral y Maxilofacial, Hospital Carlos Haya, Málaga. España.

3 Servicio de Cirugía Oral y Maxilofacial, Hospital Universitario Puerta del Mar, Cádiz. España.

4 Servicio de Otorrinolaringología, Hospital Clínico Universitario Virgen de la Victoria, Málaga. España.

5 Servicio de Cirugía Oral y Maxilofacial, Complejo Hospitalario Reina Sofía, Córdoba. España.

6 Servicio de Otorrinolaringología, Hospital Costa del Sol, Marbella-Málaga. España.

7 Servicio de Cirugía Oral y Maxilofacial, Hospital San Juan, Alicante. España.

Abstract: Objective: Maxillofacial infections are a frequent cause for consulting maxillofacial surgeons. Dental problems are the most frequent source of infections, these being typically polymicrobial. For these reasons, safety and efficacy of piperacillin/tazobactam in maxillofacial infections were evaluated in this study.

Design: Multicenter and prospective study in which seventy-nine patients with maxillofacial infections were treated with piperacillin/tazobactam.

Results: $97.5 \%$ of the evaluable patients were clinically cured or improved and the bacteriologic eradication rate was $96.2 \%$. Five out of 79 (6.3\%) had an adverse event (two dyspepsia, two dizziness and one phlebitis). No deaths were attributable to the study drug. Conclusions: Piperacillin/tazobactam is a good single drug treatment choice for maxillofacial infections.

Key words: maxillofacial infections - piperacillin-tazobactam- clinical efficacy - safety.

\section{Introduction}

Infections of the maxillofacial area constitute a frequent entity in the daily practice of the maxillofacial surgeon. When speaking of maxillofacial infection, a wide range of conditions, having a different nature, different etiology, different clinical presentation and seriousness, are included in this definition. They may go from simple cases that are treated as out-patients to entities having important morbidity-mortality that require early and aggressive intrahospital treatment.

This type of infections may endanger life either due to the mechanical involvement of the airway, due to the production of toxins or due to dissemination to distant organs by contiguity as well as by hematogenic propagation. Since the introduction of antibiotics, infections that jeopardize life are unusual and are associated with some lower mortality 
de procesos, de diferente naturaleza, diferente etiología, diferente presentación clínica y gravedad. Pueden ser desde casos simples que son tratados de forma ambulatoria hasta entidades de gran morbimortalidad que precisan un tratamiento intrahospitalario precoz y agresivo.

Este tipo de infecciones puede poner en peligro la vida bien por el compromiso mecánico de la vía aérea, por la producción de toxinas o por la diseminación a órganos distantes tanto por contigüidad como por la propagación hematógena. Desde la introducción de los antibióticos, las infecciones que comprometen la vida son inusuales y se asocian con unos índices de mortalidad menores. Sin embargo, estas infecciones siguen siendo frecuentes en pacientes alcohólicos, debilitados o inmunodeprimidos..$^{1-3}$

Dentro de las infecciones del área maxilofacial, las de origen dentario son las más comunes. La mayoría evolucionan favorablemente con complicaciones mínimas, pero también pueden acarrear una grave morbilidad y hasta ser letales. Otros cuadros como el síndrome de Lemierre, la angina de Ludwig o el absceso peritonsilar son menos frecuentes pero de extrema gravedad. .-5 $^{3}$

Los microorganismos más frecuentemente implicados son variables dependiendo de la entidad evaluada. En general, los microorganismos aislados en las infecciones de cabeza y cuello son: Estreptococos no hemolíticos (46,7\%), Estreptococos hemolíticos (11,3\%), S. epidermidis $(10,7)$, Enterobacterias (9,3\%), Peptostreptococcus spp, Bacteroides spp. (7,4\%), Enterococos (4,7\%), S. aureus (1.3\%), P. aeruginosa (1.3-10\%).6-8 Sin embargo, este porcentaje varía ampliamente según la patología. Así, en la infección odontogénica se ha demostrado una naturaleza polimicrobiana, de naturaleza predominantemente anaerobia. ${ }^{2}$ En las infecciones más graves, cualquiera que sea su origen, suele intervenir una flora mixta y se precisa un tratamiento más agresivo que combine la cirugía, la antibioterapia sistémica y otras medidas de soporte vital. ${ }^{3}$

Como se ha visto, todos estos procesos infecciosos pueden comprometer seriamente las vías aéreas superiores y requieren un diagnóstico y tratamiento precoz. Se aceptan diversas pautas de tratamiento antibiótico empírico, tanto combinado como en monoterapia. La piperacilina-tazobactam es un betalactámico de amplio espectro de la familia de las ureidopenicilinas al que se le ha asociado un inhibidor de las betalactamasas, tazobactam, para mejorar su acción frente a enterobacterias productoras de estas betalactamasas. ${ }^{9}$ Este compuesto es muy activo frente a microorganismos grampositivos, incluyendo cepas que producen betalactamasas (entre otras $\mathrm{S}$. aureus meticilín sensibles, $\mathrm{S}$. epidermidis, estreptococos y enterococos). ${ }^{10}$ Además, piperacilina-tazobactam muestra una gran actividad frente a los bacilos Gram negativos (BGN) incluida Pseudomonas aeruginosa. ${ }^{11}$ El espectro se completa con su actividad frente a microorganismos anaerobios. ${ }^{12}$

En nuestro conocimiento no se han realizado hasta la fecha estudios que evalúen la utilidad de piperacilina-tazobactam en infecciones del área maxilofacial. Por ello el objetivo de este estudio es valorar la eficacia y seguridad de un antibiótico de amplio espectro como piperacilinatazobactam en pacientes con infecciones graves del área maxilofacial.

\section{Material y método}

Se incluyeron en el estudio pacientes mayores de 18 años con infecciones en el área maxilofacial (infección de glándulas salivales, celulitis indexes. However, these infections continue to be frequent in alcoholic, weakened or immunodepressed patients. ${ }^{1-3}$

Within the infections of the maxillofacial area, the dental origin ones are the most common. Most evolve favorably with minimum complications, but they can also cause serious morbidity and even be fatal. Other pictures such as the Lemierre syndrome, Ludwig's angina or peritonsillar abscess are less frequent but extremely serious. ${ }^{3-5}$

The most frequently involved microorganisms are variable, depending on the entity evaluated. In general, the microorganisms isolated in head and neck infections are: Non-hemolytic streptococci (46.7\%), Hemolytic streptococci (11.3\%), S. epidermidis (10.7), Enterobacterias (9.3\%), Peptostreptococcus spp, Bacteroides spp. (7.4\%), Enterococci (4.7\%), S. aureus (1.3\%), P. aeruginosa (1.3-10\%)6-8. However, this percentage varies widely according to the disease. Thus, a predominantly anaerobic polymicrobial nature has been demonstrated in odontogenic infection. ${ }^{2}$ A mixed flora generally participates in the more serious infections, whatever their origin, and more aggressive treatment that combines surgery, systemic antibiotic treatment and other life support measures are required. ${ }^{3}$

As has been seen, all the infectious conditions can seriously affect the upper airways and require early diagnosis and treatment. Different empirical antibiotic treatment regimens, both combined as well as single drug therapy, are accepted. Piperacillin-tazobactam is a wide spectrum betalactamic agent from the ureidopenicillin family that has been associated to a beta-lactamase inhibitor, tazobactam, to improve its action against beta-lactamase producing enterobacterias. ${ }^{9}$ This compound is very active against gram positive microorganisms, including strains that produce betalactamases (among others methicillin susceptible S. aureus, S. epidermidis, streptococci and enterococci). 10 In addition, piperacillin-tazobactam shows a large activity against the gram negative bacilli (GNB) including Pseudomonas aeruginosa. ${ }^{11}$ The spectrum is completed with its activity against anaerobic microorganisms. ${ }^{12}$

To our knowledge, up to now no studies have been done that evaluate the usefulness of piperacillin-tazobactam in infections of the maxillofacial area. Thus, this study aims to assess the efficacy and safety of a wide spectrum antibiotic such as piperacillin-tazobactam in patients with serious infections of the maxillofacial area.

\section{Material and method}

Included in the study were patients older than 18 years of age with infections in the maxillofacial area (infection of the salivary glands, cellulitis of sinus origin, cellulitis of dermal origin, cellulitis of dental origin, Ludwig's angina, cervical adenophlegmon, peritonsillar abscess, cervical necrotizing fasciitis) that had or lacked suppuration, that required drainage or surgical debridement or not, and whose treatment with piperacillin-tazobactam was administered for a 
Tabla 1. Tabla valoración del paciente.

\begin{tabular}{|c|c|c|c|c|c|}
\hline & 0 & 1 & 2 & 3 & 4 \\
\hline Temperatura Axilar & $<37^{\circ} \mathrm{C}$ & $37^{\circ} \mathrm{C}-37,5^{\circ} \mathrm{C}$ & $37,5^{\circ} \mathrm{C}-38^{\circ} \mathrm{C}$ & $38^{\circ} \mathrm{C}$ & \\
\hline Fatiga General & & No & Sí & & \\
\hline Anorexia & & No & Sí & & \\
\hline Rubor (No boca) & No eritema & Eritema $<1 \mathrm{~cm}$ & Eritema $1-5 \mathrm{~cm}$ & & \\
\hline Dificultad apertura de boca & $\geq 30 \mathrm{~mm}$ & $20-30 \mathrm{~mm}$ & $10-20 \mathrm{~mm}$ & $<10 \mathrm{~mm}$ & \\
\hline Tumefacción (no boca) & Ninguna & & Menor $1 \mathrm{~cm}$ & & $1,5 \mathrm{~cm}$ \\
\hline Induración & No & Sí & & & \\
\hline Dolor & No & Ligero (1-5) & Intenso (6-10) & & \\
\hline Linfadenopatias & No & Móvil & Fija & & \\
\hline
\end{tabular}

Table 1. Assessment of patient.

\begin{tabular}{|c|c|c|c|c|c|}
\hline & 0 & 1 & 2 & 3 & 4 \\
\hline Axillary Temperature & $<37^{\circ} \mathrm{C}$ & $37^{\circ} \mathrm{C}-37.5^{\circ} \mathrm{C}$ & $37.5^{\circ} \mathrm{C}-38^{\circ} \mathrm{C}$ & $>38^{\circ} \mathrm{C}$ & \\
\hline General Fatigue & & No & Yes & & \\
\hline Anorexia & & No & Yes & & \\
\hline Rubor (Not mouth) & No erythema & Erythema $<1 \mathrm{~cm}$ & Erythema $1-5 \mathrm{~cm}$ & & \\
\hline Difficulty of mouth opening & $\geq 30 \mathrm{~mm}$ & $20-30 \mathrm{~mm}$ & $10-20 \mathrm{~mm}$ & $<10 \mathrm{~mm}$ & \\
\hline Swelling (not mouth) & None & & Less than $1 \mathrm{~cm}$ & & $1-5 \mathrm{~cm}$ \\
\hline Induration & No & Yes & & & \\
\hline Pain & No & Mild (1-5) & Intense (6-10) & & \\
\hline Lymphadenopathies & No & Moveable & Fixed & & \\
\hline
\end{tabular}

de origen sinusal, celulitis de origen dérmico, celulitis de origen dentario, angina de Ludwig, adenoflemón cervical, absceso periamigdalar, fascitis necrotizante cervical) que presentaran o ausencia de supuración, que precisaron o no drenaje o desbridamiento quirúrgico, y siempre que el tratamiento con piperacilina-tazobactam se administró durante un mínimo de 3 días. Se consideraron criterios de exclusión la hipersensibilidad a betalactámicos, alteración renal moderada o grave, alteración hepática, granulocitopenia menor de $1.000 / \mathrm{mm}^{3}$, trombocitopenia menor de $50.000 / \mathrm{mm}^{3}$ así como la presencia de otra infección concomitante documentada clínica o bacteriológicamente en el momento de inclusión del paciente.

Las muestras para el procesamiento microbiológico se obtuvieron por punción y aspiración de la zona afectada o mediante torunda tras el tratamiento quirúrgico.

Los pacientes salieron del estudio ante toxicidad grave general según el criterio del médico responsable, pérdida de seguimiento o abandono voluntario y aquellos en los que tras 72 horas de tratamiento no se objetivó una respuesta favorable o no se obtuviera respuesta.

Elaboramos un cuaderno de recogida de datos, donde se incluyeron las características demográficas, factores predisponentes, datos clínicos y analíticos, microbiología de la lesión, tratamientos médicos o quirúrgicos asociados y evaluación de la respuesta clínica y microbiológica al tercer día y al final del tratamiento. Con relación a la aparición de reacciones adversas, se consideró su relación causal con el fármaco del estudio (definitiva, probable, posible y remota), su graduación en cuanto a la gravedad (leve, moderada, grave, amenazante para la vida), y el tipo de actuación empleado para eliminarla. minimum of 3 days. Exclusion criteria were considered to be hypersensitivity to beta-lactamics, moderate or serious renal alteration, hepatic alteration, granulocytopenia less than $1,000 / \mathrm{mm}^{3}$, thrombocytopenia less than $50,000 / \mathrm{mm}^{3}$ as well as the presence of another concomitant infection clinically or bacteriologically documented at the time of the patient's inclusion.

Samples for the microbiological processing were obtained by puncture and aspiration of the zone affected or by swab after the surgical treatment.

The patients abandoned the study when there was serious general toxicity according to the judgment of the responsible physician, loss to follow-up or voluntary drop-out and those in whom no favorable response was seen or no response was obtained after 72 hours of treatment.

We elaborated a case report form, that included demographic characteristics, predisposing factors, clinical and analytic data, microbiology of the lesion, associated surgical or medical treatments and evaluation of the clinical and microbiological response on the third day and at the end of the treatment. In relationship to the appearance of adverse reactions, its causal relationship with the study drug (definitive, probable, possible and remote), its grading in regards to seriousness (mild, moderate, serious, life threatening) and the type of action used to eliminate it were considered. 


\section{Evaluación clínica}

Con el fin de objetivar la respuesta al tratamiento se diseñó un sistema de puntuación para valorar la situación del enfermo. En la tabla 1 se indican los parámetros evaluados así como la puntuación correspondiente a cada uno de los mismos. Se realizó esta evaluación en el día del inicio del tratamiento, al tercer, al quinto día y al finalizar el tratamiento.

Definimos el ratio de respuesta como la puntuación del día que se estaba evaluando al paciente dividida por la puntuación del primer día. Así se consideró la respuesta como favorable si el ratio fue menor de 0,7. Si era menor de 0,3 se consideró excelente y si se encontraba entre 0,3 y 0,7 efectivo. Se estimó fracaso del tratamiento cuando el ratio fue mayor o igual a 0.7 según la misma escala. Del mismo modo se consideró como fracaso del tratamiento la necesidad de realizar drenaje una vez iniciado el tratamiento antibiótico o el cambio de antibioticoterapia.

Se consideró no evaluable cuando la infección era de origen fúngico o viral o cuando alguno de los microorganismos aislados era resistente a piperacilina-tazobactam.

\section{Evaluación microbiológica}

Se evaluó la eficacia microbiológica según los siguientes parámetros. Definimos erradicación cuando se eliminaron todos los microorganismos aislados en la muestra inicial; presunta erradicación cuando existía mejoría clínica pero no se realizaron cultivos microbiológicos para confirmar la erradicación; persistencia cuando el microorganismo original se aisló en cultivos sucesivos y la colonización se definió como la aparición de un nuevo microorganismo, distinto del causante de la infección inicial, si bien dicho aislamiento no se acompañaba de signos clínicos sugestivos de infección. Se consideró recaída la reaparición del mismo microorganismo una vez cesado el tratamiento y reinfección como la aparición de un nuevo microorganismo una vez concluido el tratamiento.

\section{Descripción del tratamiento}

La presentación de Piperacilina-tazobactam es en viales de 4/0,5 g como polvo apirógeno liofilizado. La dilución se realizó con suero salino fisiológico y se administra por vía intravenosa en perfusión continua durante 30 minutos. La dosis aplicada fue de 4/0,5 g cada ocho horas. No se permitió la administración de otro antibiótico de manera simultánea al estudio. En caso de que el microorganismo responsable de la infección no fuese sensible a piperacilina-tazobactam, se ajustó el tratamiento según el antibiograma. Cuando la evolución del enfermo lo permitió se sustituyó piperacilina-tazobactam por otro antibiótico que se pudiera administrar por vía oral.

\section{Diseño del estudio}

Es un estudio multicéntrico, prospectivo y observacional. El análisis se efectuó según intención de tratar, es decir, la duración del periodo de seguimiento de cada paciente se entenderá como el tiempo hasta la aparición de uno de los sucesos clínicos que corroboran la eficacia del tratamiento o hasta el final del estudio.

\section{Resultados}

Se incluyeron en el estudio 79 pacientes con una edad media de 36,3 años (DE: 14,9 años), la distribución por sexos fue de 59\% varo-

\section{Clinical evaluation}

In order to observe response to treatment, a scoring system was designed to assess the patient's situation. Table 1 shows the parameters evaluated as well as the score corresponding to each one of them. This evaluation was performed on the day of the onset of treatment, the third day, fifth day and at the end of the treatment.

We define response ratio as the score of the day that the patient was being evaluated divided by the score of the first day. Thus, response was considered as favorable if the ratio was less than 0.7. If it was less than 0.3 , it was considered excellent and if it was between 0.3 and 0.7 , effective.

Treatment failure was considered to exist when the ratio was greater than or equal to 0.7 according to the same scale. In the same way, the need to perform drainage once antibiotic treatment was initiated or change the antibiotic treatment was considered as treatment failure.

It was considered to be non-evaluable when the infection had a fungal or viral origin or when some of the microorganisms isolated were resistant to piperacillin-tazobactam. Microbiological evaluation

Microbiological efficacy was evaluated according to the following parameters. We defined eradication as when all the microorganisms isolated in the initial sample were eliminated; presumed eradication when there was clinical improvement but no microbiological cultures were performed to verify the eradication; persistence when the original microorganism was isolated in successive cultures and colonization was defined as the appearance of a new microorganism, different from that causing the initial infection, although this isolation was not accompanied by clinical signs suggestive of infection. Relapse was considered to be the reappearance of the same microorganism once treatment was stopped and reinfection as the appearance of a new microorganism once the treatment was completed.

\section{Description of the treatment}

Piperacillin-tazobactam is presented in vials of $4 / 0.5 \mathrm{~g}$ as apyrogenic lyophilized powder. Dilution was performed with saline solution and administered intravenously in continuous perfusion for 30 minutes. The dose applied was 4/0.5 $g$ every eight hours. Administration of another antibiotic was not permitted simultaneously to the study. If the microorganism responsible for the infection was not susceptible to piperacillin-tazobactam, treatment was adjusted according to the antibiogram. When the evolution of the patient made it possible, piperacillin-tazobactam was substituted by another antibiotic that could be administered orally.

\section{Study design}

It is a multicentric, prospective and observational study. The analysis was performed according to intention to treat, that is, the duration of the follow-up period of each patient will be understood as the time to appearance of one of the clinical events that corroborate the efficacy of the treatment or until the end of the study. 
Tabla 2. Relación de diagnósticos.

$\begin{array}{lc}\text { DIAGNÓsTICO } & N^{\circ} \text { DE CASOS } \\ \text { Celulitis } & 54 \\ \text { Infección glándulas salivales } & 8 \\ \text { Infección postquirúrgica } & 6 \\ \text { Absceso periamigdalar } & 8 \\ \text { Adenoflemón cervical } & 3 \\ \text { Angina Ludwig } & 2 \\ \text { Pericondritis } & 2 \\ \text { Fascitis necrotizante cervical } & 1 \\ \text { Sinusitis } & 1 \\ \text { Epiglotitis } & 1 \\ \text { Herida posttraumática } & 1 \\ \text { Quiste cavum sobreinfectado } & 1\end{array}$

Tabla 3. Evaluación clínica.

$\begin{array}{ccc}\begin{array}{c}\text { Evaluación 3er día } \\ \mathrm{N}=\mathbf{7 9}\end{array} & \begin{array}{c}\text { Evaluación } \mathbf{5}^{\circ} \text { día } \\ \mathrm{N}=\mathbf{2 9}\end{array} & \begin{array}{c}\text { Evaluación final } \\ \mathrm{N}=\mathbf{7 9}\end{array} \\ & & \\ \text { Favorable (75) } & \text { Favorable (29) } & \text { Favorable (77) } \\ \text { Excelente: } 32 & \begin{array}{c}\text { Excelente: } 20 \\ \text { Efectivo: } 9\end{array} & \\ \text { Efectivo: } 43 & & \text { Fracaso (2) } \\ \text { Desfavorable (4) } & & \\ \text { Fracaso: } 4 & & \end{array}$

nes y $41 \%$ mujeres. El $22,7 \%$ de los pacientes eran bebedores habituales y el 40,5\% fumadores. Los diagnósticos incluían (Tabla 2): celulitis de cualquier origen: 54 casos; infección de glándulas salivales: 8 casos; absceso periamigdalar: 8 casos; infección postquirúrgica: 6 casos; adenoflemón cervical en 3 casos; angina de Ludwig: 2 casos y otros diagnósticos en 7 casos.

La puntuación media de la situación del enfermo en la valoración inicial del paciente fue de 12,9 (DE: 3,6, rango: 7-26). Siete pacientes $(8,9 \%)$ presentaron disnea en la evaluación de inicio y $38(48,1 \%)$ disfagia u odinofagia coincidiendo con el diagnóstico. Treinta y ocho pacientes precisaron cirugía $(48,1 \%)$ y en 31 casos se realizó la colocación de uno o varios drenajes $(39,2 \%)$.

La duración media del tratamiento fue de 4,1 días (DE: 1,5 días). Cincuenta pacientes recibieron menos de cinco días de tratamiento. La respuesta clínica al tercer y quinto día del tratamiento antibiótico se muestran en la tabla 3.

La evolución clínica final de todos los pacientes $(n=79)$ al finalizar el tratamiento fue favorable en el $97,5 \%$ de los pacientes $(77 / 79)$ y desfavorable en el $2,5 \%$ restante (2/79). En los dos casos de evolución desfavorable, la infección estuvo producida por microorganismos resistentes a piperacilina-tazobactam, en un caso S. aureus resistente a meticilina y en otro por Mucor.

Se consiguió aislar algún microorganismo en 30 casos, de los que 12 casos eran polimicrobianos. En la tabla 4 se pueden ver los microorganismos aislados más frecuentemente.
Table 2. Infection and oral communication.

\section{DIAGNOSES}

Cellulitis

Salivary gland infection

Peritonsillar abscess

Cervical Adenophlegmon

Ludwig's Angina

Perichondritis

Cervical narcotizing fasciitis

Sinusitis

Epiglottitis

Post-traumatic wound

Overinfected cavum cyst
Post-surgical infection
NO. OF CASES

54

8

6

8

3

2

2

1

1

1

1
Table 3. Clinical evaluation.

\begin{tabular}{|c|c|c|}
\hline $\begin{array}{l}\text { Evaluation } 3^{\text {rd }} \text { day } \\
\qquad N=79\end{array}$ & $\begin{array}{l}\text { Evaluation } 5^{\text {th }} \text { day } \\
\qquad \mathrm{N}=29\end{array}$ & $\begin{array}{l}\text { Final evaluation } \\
\qquad N=79\end{array}$ \\
\hline $\begin{array}{c}\text { Favourable (75) } \\
\text { Excellent: } 32 \\
\text { Effective: } 43\end{array}$ & $\begin{array}{c}\text { Favourable (29) } \\
\text { Excellent: } 20 \\
\text { Effective: } 9\end{array}$ & Favorable (77) \\
\hline $\begin{array}{c}\text { Unfavourable (4) } \\
\text { Failure: } 4\end{array}$ & & Failure (2) \\
\hline
\end{tabular}

\section{Results}

A total of 79 patients with a mean age of 36.3 years (SD: 14.9 years) were included in the study. Distribution by genders was $59 \%$ men and $41 \%$ women. A total of $22.7 \%$ of the patients were usual drinkers and $40.5 \%$ smoked. The diagnoses included (Table 2): cellulitis of any origin: 54 cases; infection of salivary glands: 8 cases; peritonsillar abscess: 8 cases; postsurgical infection. 6 cases; cervical adenophlegmon in 3 cases; Ludwig's angina: 2 cases and other diagnoses in 7 cases.

The mean score of the situation of the patient in the initial assessment of the patient was 12.9 (SD: 3.6, range: 726). Seven patients (8.9\%) presented dyspnea in the onset assessment and 38 (48.1\%) dysphagia or odynophagia coinciding with the diagnosis. Thirty eight patients required surgery (48.1\%) and placement of one or several drainages was performed in 31 cases (39.2\%).

Mean treatment duration was 4.1 days (SD: 1.5 days). Fifty patients received less than five days of treatment. Clinical response on the third and fifth day of antibiotic treatment is shown in table 3.

The final clinical evolution of all the patients $(n=79)$ at the end of the treatment was favorable in $97.5 \%$ of the patients (77/79) and unfavorable in the remaining 2.5\% (2/79). In the two cases having unfavorable evolution, infection was pro- 
Tabla 4. Microorganismos aislados.

$\begin{array}{ll}\text { MICROORGANISMOS AISLADOS } & \text { N }^{\mathbf{0}} \\ \text { Flora habitual } & 6 \\ \text { S. aureus } & 6 \\ \text { S. viridans } & 5 \\ \text { Streptococcus spp } & 4 \\ \text { P. aeruginosa } & 4 \\ \text { Bacteroides spp } & 2 \\ \text { Klebsiella spp } & 2 \\ \text { Peptococcus spp } & 1 \\ \text { Prevotella spp } & 1 \\ \text { Proteus spp } & 1 \\ \text { S. betahemolitico } & 1 \\ \text { Serratia marcenscens } & 1 \\ \text { S. pneumoniae } & 1\end{array}$

Tabla 5. Evaluación microbiológica.

$\begin{array}{lccc} & \begin{array}{c}\text { 3er DíA } \\ \text { N=79 }\end{array} & \begin{array}{c}5^{\circ} \text { DíA } \\ \text { N=29 }\end{array} & \begin{array}{c}\text { FINAL } \\ \text { N=79 }\end{array} \\ \text { Erradicación } & 7 & 6 & 10 \\ \text { Presunta erradicación } & 67 & 23 & 66 \\ \text { Colonización } & 1 & & 1 \\ \text { Persistencia } & 2 & & \\ \text { No valorable } & 2 & & 2\end{array}$

Table 4. Isolated microorganisms.

$\begin{array}{ll}\text { ISOLATED MICROORGANISMS } & \text { N }^{\circ} \\ & \\ \text { Usual Flora } & 6 \\ \text { S. aureus } & 6 \\ \text { S. viridans } & 5 \\ \text { Streptococcus spp } & 4 \\ \text { P. aeruginosa } & 4 \\ \text { Bacteroides spp } & 2 \\ \text { Klebsiella spp } & 2 \\ \text { Peptococcus spp } & 1 \\ \text { Prevotella spp } & 1 \\ \text { Proteus spp } & 1 \\ \text { Betahemolytic S. } & 1 \\ \text { Serratia marcenscens } & 1 \\ \text { S. pneumoniae } & 1\end{array}$

Table 5. Microbiological evaluation.

$\begin{array}{lccc} & \begin{array}{c}3^{\text {th }} \text { DAY } \\ \mathbf{N}=\mathbf{7 9}\end{array} & \begin{array}{c}5^{\text {th }} \text { DAY } \\ \mathbf{N}=\mathbf{2 9}\end{array} & \begin{array}{c}\text { FINAL } \\ \mathrm{N}=\mathbf{7 9}\end{array} \\ \text { Eradication } & 7 & 6 & 10 \\ \text { Presumed eradication } & 67 & 23 & 66 \\ \text { Colonization } & 1 & & 1 \\ \text { Persistence } & 2 & & \\ \text { Not evaluable } & 2 & & 2\end{array}$

La eficacia microbiológica obtenida al final del tratamiento fue del $96,2 \%$, distribuida en un $12,6 \%$ de casos de erradicación (eliminación de los microorganismos originales) y un $85,5 \%$ de casos de presunta erradicación (con mejoría clínica pero sin que se puedan aislar los microorganismos). En la tabla 5 se muestra la eficacia microbiológica al tercer y quinto día de tratamiento. ${ }^{13}$

Las reacciones adversas relacionadas con el empleo de piperacilina-tazobactam se presentaron en 5 pacientes (leves en los cinco casos), apareciendo dos casos de mareo, dos de dispepsia y un caso de flebitis. En ningún caso se precisó la discontinuación del fármaco.

Veintitrés pacientes no presentaron fiebre en el momento del diagnóstico, en los restantes el tiempo medio de desaparición de la fiebre fue de 1,5 días (DE: 0,76 días). La estancia hospitalaria media fue de 5,3 días (DE: 3,31 días). No se produjo ningún fallecimiento.

\section{Discusión}

Las infecciones del área maxilofacial representan un motivo habitual de consulta para los cirujanos maxilofaciales. Dentro de la gran variedad de entidades que se agrupan bajo este término, las infecciones de origen dental son las más frecuentes. Esto se corrobora en nuestro estudio donde la mayoría de los casos se trataban de celulitis $(61,4 \%)$, y dentro de ellas, la más frecuente, fue la celulitis de origen dentario.

Existen una serie de factores, generales y locales, que influyen en la diseminación del proceso infeccioso. La infección se disemina a par- duced by piperacillin-tozobactam resistant microorganisms, in one case methicillin resistant $S$. aureus and in the other due to Mucor. It was possible to isolate some microorganism in 30 cases, 12 of which were polymicrobial. The microorganisms isolated most frequently can be seen in table 4.

Microbiological efficacy obtained at the end of the treatment was $96.2 \%$, distributed in $12.6 \%$ of eradication cases (elimination of the original microorganisms) and $85.5 \%$ of cases of presumed eradication (with clinical improvement however, it was not possible to isolate the microorganisms). Table 5 shows the microbiological efficacy on the third and fifth day of treatment (13).

Adverse reactions related with the use of piperacillin-tazobactam presented in 5 patients (mild in the five cases), with two cases of dizziness, two of dyspepsia and one case of phlebitis. Discontinuation of the drug was not required in any case.

Twenty three patients did not present fever at the time of the diagnosis; in the rest, the mean time of disappearance of the fever was 1.5 days (SD: 0.76 days). The mean hospital stay was 5.3 days (SD: 3.31 days). No deaths were produced.

\section{Discussion}

Infections of the maxillofacial area represent a usual reason for a visit to the maxillofacial surgeons. Infections of den- 
tir del diente y hueso alveolar de una forma relativamente radial; una vez que atraviesa el hueso y el periostio, la propagación por las partes blandas se ve condicionada por la posición de los músculos y aponeurosis regionales. Se han descrito muchos espacios en la cabeza y cuello, algunos son hendiduras (espacios virtuales entre espacios aponeuróticos) y otros verdaderos compartimentos con tejido conectivo y diversas estructuras anatómicas. Los compartimentos sublingual, submaxilar, látero y retrofaríngeo son los más peligrosos por el posible compromiso del paso del aire o por la extensión a territorios vitales como el mediastino. El conocimiento de estos espacios permite valorar la localización idónea de la incisión quirúrgica, cuando está indicada. En general, el éxito del tratamiento de estas infecciones reside en un tratamiento correcto precoz.

El tratamiento antibiótico persigue detener la extensión local de la infección, rebajar el inóculo bacteriano en el foco infeccioso y prevenir las complicaciones derivadas de la diseminación hematógena. Mientras que en los casos leves y moderados se puede recurrir a antibióticos orales, en el caso de infecciones graves se requiere el ingreso hospitalario, con medidas de soporte vital y la administración de antibióticos parenterales con actividad de amplio espectro.

En general, la mayoría de los microorganismos en pacientes sanos, tanto aerobios como anaerobios, son sensibles a la penicilina. El problema de la producción de betalactamasas y la resistencia a penicilina entre ciertos anaerobios orales está aumentando y por ello se han visto fracasos del tratamiento con penicilina en infecciones producidas por estos microorganismos. En pacientes con infecciones graves, que pueden poner en peligro la vida y en pacientes que tienen una mala respuesta o una respuesta lenta a la penicilina se deben utilizar tratamientos alternativos con antibióticos de mayor espectro con actividad frente a anaerobios así como a bacilos gramnegativos.

Los pacientes ambulatorios pueden tratarse con amoxicilina con o sin un inhibidor de betalactamasas o con penicilina o una fluoroquinolona en combinación con metronidazol. También se pueden utilizar clindamicina o cefoxitina. Sin embargo, la creciente resistencia de los microorganismos anaerobios a estos fármacos limita su utilidad. La eritromicina y las tetraciclinas no se recomiendan debido a la creciente resistencia entre algunas cepas de Streptococcus. ${ }^{2}$ Metronidazol, aunque es muy activo frente a los bacilos gramnegativos anaerobios y las espiroquetas es sólo moderadamente activo frente a los cocos anaerobios y no es activo frente a los microorganismos aerobios, incluyendo Streptococcus. ${ }^{14}$

En los pacientes con cuadros más graves, que precisan hospitalización, existen microorganismos como P. aeruginosa que juegan un papel fundamental, tal como hemos visto en este estudio. Por ello, sería prudente en estos pacientes cubrir bacilos gramnegativos facultativos, entre ellos $\mathrm{P}$. aeruginosa, y microorganismos anaerobios. ${ }^{15-20}$ Tradicionalmente el tratamiento en monoterapia de estas infecciones se realizaba con amoxicilina-clavulánico. Sin embargo, el papel cada vez más importante de P.aeruginosa en estas patologías, corroborada en nuestro estudio, podría limitar su papel en el tratamiento empírico de pacientes graves con este tipo de infecciones. Otro aspecto que condiciona los problemas del tratamiento empírico con amoxicilina-clavulánico es la creciente resistencia de los bacilos gramnegativos entéricos, en especial E.coli. En nuestro medio, estudios recientes sobre cepas de origen urinario, la resistencia gira en torno a un $6 \%,{ }^{21} \sin$ embargo, en tal origin are the most frequent within the large variety of entities that are grouped under this term. This is corroborated in our study where most of the cases were cellulitis (61.4\%). Within these, cellulitis of dental origin was the most frequent.

There are a series of general and local factors that influence the spread of the infectious condition. The infection is spread from the tooth and alveolar bone in a relatively radial way; once it crosses over the bone and periosteum, the dissemination through the soft tissues is conditioned by the position of the muscles and regional aponeurosis. Many spaces in the head and neck have been described, some with fissures (virtual spaces between aponeurotic spaces) and other true compartments with connective tissue and diverse anatomical structures. The sublingual, submaxillary, lateroand retropharyngeal compartments are the most dangerous due to the possible involvement of the air passage or by extension to vital territories such as the mediastinum. Knowledge of these spaces makes it possible to assess the best location of the surgical incision, when this is indicated. In general, treatment success of these infections is found in an early correct treatment.

The antibiotic treatment attempts to stop local extension of the infection, reduce bacterial inoculum in the infectious focus and prevent complications derived from the hematogenic dissemination. While oral antibiotics can be used in mild and moderate cases, hospitalization is required in the case of serious infections, with measures of life support and the administration of parenteral antibiotics with wide spectrum activity.

In general, most of the microorganisms in healthy patients, both aerobic as well as anaerobic, are susceptible to penicillin. The problem of the production of beta-lactamases and resistance to penicillin among certain oral anaerobes is increasing and thus treatment failure with penicillin in infections produced by these microorganisms has been seen. In patients with serious infections, that can be life threatening and in patients who have poor or slow response to penicillin, alternative treatments with greater spectrum antibiotics with activity against anaerobes as well as gram negative bacilli should be used.

Out-patients can be treated with anoxicillin with or without a beta-Iactamase inhibitor or with penicillin or a fluoroquinolone in combination with metronidazole. Clindamycin or cefoxitin can also be used. However, the growing resistance of anaerobic microorganisms to these drugs limits their utility. Erythromycin and tetracyclines are not recommended due to the growing resistance among some strains of Streptococcus. ${ }^{2}$ Although Metronidazole is very active against gram negative anaerobic bacilli and the spirochetes, it is only moderately active against anaerobic cocci and is not active against aerobic microorganisms, including Streptococcus. ${ }^{14}$

In patients with more serious pictures, that require hospitalization, there are microorganisms such as $P$. aeruginosa 
Francia se refieren resistencias de hasta un 37\%.22 Además, tazobactam aporta una mejor inhibición de las betalactamasas del tazobactam que del clavulánico,23 y la menor inducción de éstas. ${ }^{24,25}$

En muchos casos, el tratamiento antibiótico no será suficiente para erradicar la infección y por eso debe acompañarse de otras medidas como el drenaje del absceso, la cirugía o la extracción dentaria. En nuestro estudio, el $48,1 \%$ de los casos precisó cirugía y el 39,2\% la colocación de uno o varios drenajes.

Respecto a la actitud diagnóstica, la situación ideal sería aquella que permitiera conocer con exactitud los microorganismos implicados en cada proceso y adaptar de este modo el tratamiento antibiótico. Sin embargo, en las infecciones maxilofaciales, esto no es una tarea fácil. Por un lado, la gran variedad de microorganismos aerobios y anaerobios aislados y por otro, la obtención de muestras clínicas contaminadas con flora comensal añade dificultad al aislamiento microbiológico. Cuando se intenta la obtención de muestras para el diagnóstico microbiológico de las infecciones profundas de la cabeza y cuello hay que prestar especial cuidado a la contaminación con la flora habitual de la zona. Esto puede lograrse mediante un abordaje extraoral mediante aspiración con jeringa o bien mediante drenaje quirúrgico. El tratamiento de estas infecciones deberá individualizarse en cada caso. Sin embargo y a pesar de sus limitaciones, el estudio microbiológico es fundamental y debería realizarse siempre que fuera posible, para un mejor conocimiento de los microorganismos implicados en esta patología. Esto permitiría un mejor ajuste del tratamiento antibiótico empírico que es el habitual.

Durante las pasadas décadas, la naturaleza predominantemente anaerobia de la flora de las infecciones odontogénicas se ha puesto de manifiesto. Brook encuentra que en el $50 \%$ de las infecciones profundas de origen odontogénico se aislaron solamente microorganismos anaerobios, en el $44 \%$ una flora mixta aero-anaerobia y sólo en el $6 \%$ un cultivo puro de microorganismos aerobios. ${ }^{26}$ Nuestro estudio muestra una proporción especialmente baja de microorganismos anaerobios, esto podría deberse a dos hechos, primero se han incluido patologías no odontogénicas, donde la flora sería la propia de otras infecciones de piel y tejidos blandos y segundo la toma de la muestra no siempre se realizó en las condiciones adecuadas para el cultivo de microorganismos anaerobios. En general, el estudio microbiológico no se ha realizado en tantas ocasiones como sería deseable. En nuestra opinión, esto se debe a la dificultad del diagnóstico microbiológico en las infecciones maxilofaciales. Por una parte, el gran número de infecciones odontogénicas en las que es difícil precisar el papel de los microorganismos aislados, bien como responsables del cuadro infeccioso, bien como flora comensal. En otras ocasiones, microorganismos que se consideran flora habitual en esta zona pueden ser los responsables de la infección. También es llamativo en nuestro estudio el aislamiento de P. aeruginosa. Esta flora es más propia en casos de pacientes muy graves, con distintas patologías de base y que precisan ingreso. En nuestro estudio, P. aeruginosa representa el cuarto microorganismo por orden de frecuencia aislado en estos pacientes, incluso si incluimos microorganismos propios de la flora orofaríngea. Por ello, en estos pacientes con cuadros más graves que precisan hospitalización y con patología de base sería razonable cubrir P. aeruginosa en el tratamiento empírico inicial.

Nuestro estudio comunica resultados que alcanzan el de evolución clínica favorable en el $97,5 \%$ de los casos con el empleo de piperaci- that play a fundamental role, as we have seen in this study. Thus, it would be wise in these patients to cover facultative gram negative bacilli, among them $P$. aeruginosa, and anaerobic microorganisms. ${ }^{15-20}$ Traditionally, treatment of these infections with single drug therapy was performed with anoxicillin-clavulanic acid. However, the increasingly important role of $P$. aeruginosa in these diseases, corroborated in our study, could limit their role in the empiric treatment of serious patients with this type of infections. Another aspect that conditions the problems of empiric treatment with amoxicillin-clavulanic acid is the growing resistance of enteric gram negative bacilli, especially E.coli. In our setting, in recent studies with strains of urinary origin, the resistance is at about $6 \%, 21$ however, in France, resistances up to $37 \%$ are reported.22 In addition, tazobactam supplies better inhibition of the beta-lactamases of tazobactam than of clavulanic acid ${ }^{23}$ and less induction of them. ${ }^{24,25}$

In many cases, antibiotic treatment will not be sufficient to eradicate the infection and thus should be accompanied by other measures such as abscess drainage, surgery or dental extraction. In our study, $48.1 \%$ of the cases required surgery and $39.2 \%$ the placement of one or several drainages.

Regarding the diagnostic attitude, the ideal situation would be that which makes it possible to accurately know the microorganisms involved in each condition and adapt the antibiotic treatment in this way. However, in maxillofacial infections, this is not an easy task. On the one hand, the large variety of aerobic and anaerobic microorganisms isolated and on the other hand, the obtaining of clinical samples contaminated with commensal flora, adds difficulty to the microbiological isolation. When an attempt is made to obtain samples for the microbiological diagnosis of the infections deep in the head and neck, special care must be given to contamination of the usual flora of the zone. This can be achieved by an extraoral approach with aspiration with syringe or by surgical drainage. Treatment of these infections should be individualized in each case. However, and in spite of its limitations, the microbiological study is essential and should always be performed when possible, for better knowledge of the microorganisms involved in this disease. This would allow for better adjustment of the empiric antibiotic treatment than the usual one.

During the past decades, the predominantly anaerobic nature of the flora of odontogenic infections has been observed. Brook found that $50 \%$ of the deep infections of odontogenic origin only isolated anaerobic microorganisms, in 44\% a mixed aero-anaerobic flora and a pure culture of aerobic microorganism only in 6\% (26). Our study shows an especially low proportion of anaerobic microorganisms. This could be due to two facts, first, non-odontogenic diseases have been included, in which the flora would be characteristic of other infections of the skin and soft tissues and second, the sample was not always obtained in adequate conditions for the culture of anaerobic microorganisms. In general, the microbiological study was not performed as 
lina-tazobactam en monoterapia con una muy escasa incidencia de efectos adversos (6,3\% de los pacientes) y que en ningún caso obligó a la suspensión del fármaco. Esto pone de manifiesto la utilidad del tratamiento antibiótico en monoterapia en este tipo de infección, como ya ha sido demostrado en otro tipo de patologías infecciosas. Se debe también considerar el ahorro económico que supone este tipo de antibioterapia. ${ }^{27}$

\section{Conclusiones}

En conclusión, la eficacia clínica y microbiológica junto con la escasez de efectos adversos presentados hace de piperacilina-tazobactam una alternativa eficaz en el manejo de este tipo de infecciones.

\section{Bibliografía}

1. Flynn TR. Surgical management of orofacial infections. Oral Maxillofac Surg Clin North Am 2000;8:77-100.

2. Flynn TR. The swollen face. Severe odontogenic infections. Emerg Med Clin North Am 2000;18:481-519.

3. Gradon JD. Space-occupying and life-threatening infections of the head, neck, and thorax. Infect Dis Clin North Am 1996;10:857-78.

4. Biederman GR, Dodson TB. Epidemiologic review of facial infections in hospitalized pediatric patients. J Oral Maxillofac Surg 1994;52:1042-5.

5. Blomquist IK, Bayer AS. Life-threatening deep fascial space infections of the head and neck. Infect Dis Clin North Am 1988;2:237-64.

6. Hotz G, Novotny-Lenhard J, Kinzig M, Soergel F. Single-dose antibiotic prophylaxis in maxillofacial surgery. Chemother 1994;40:65-9.

7. Rodrigo J, Alvarez J, Gómez J. Comparison of three prophylactic antibiotic regimens in clean-contaminated head and neck surgery. Head Neck 1997; 19:188-93.

8. Rodrigo Tapia J, Alvarez Mendez JS, Suarez Nieto C. Bacteriologia de las infecciones de la herida quirúrgica en cirugia oncológica de cabeza y cueIlo. Acta Otorrinolaring Esp 1997;48:389-91.

9. Aronoff SC, Jacobs MR, Johenning S, Yamabe S. Comparative activities of the beta-lactamase inhibitors YTR 830 , sodium clavulanate, and sulbactam combined with amoxicillin or ampicillin. Antimicrob Agents and Chemother 1984;26:580-2.

10. Jones RN, Pfaller MA, Fuchs PC, Aldridge K, Allen SD, Gerlach EH. Piperacillin/tazobactam (YTR 830) combination. Comparative antimicrobial activity against 5889 recent aerobic clinical isolates and 60 Bacteroides fragilis group strains. Diag Microbio Infec Dis 1989;12:489-94.

11. Murray PR, Cantrell HF, Lankford RB. Multicenter evaluation of the in vitro activity of piperacillin-tazobactam compared with eleven selected beta-lactam antibiotics and ciprofloxacin against more than 42,000 aerobic grampositive and gram-negative bacteria. In Vitro Susceptibility Surveillance Group. Diag Microbiol Infect Dis 1994;19:111-20.

12. Appelbaum PC. Comparative susceptibility profile of piperacillin/tazobactam against anaerobic bacteria. J Antimicrob Chemother 1993;31 Suppl A:2938.

13. Chapnick EK, Gradon JD, Kim YD, Narvios A, Gerard P, Till M, y cols. Fatal measles pneumonia in an immunocompetent patient-- case report [carta]. Clin Infect Dis 1992;15:377-9. much as would be desired. In our opinion, this is due to the difficulty of the microbiologic diagnosis in maxillofacial infections. On the one hand, there is the large number of odontogenic infections in which it is difficult to specify the role of the microorganisms isolated, either as responsible for the infectious picture, or as a commensal flora. On other occasions, microorganisms that are considered usual flora in this zone may be responsible for the infection. The isolation of $P$. aeruginosa also stands out in our study. This flora is more characteristic in cases of very serious patients, with different baseline diseases and who require hospitalization. In our study, P. aeruginosa represents the fourth microorganism characteristic of the oropharyngeal flora. Thus, it would be reasonable to cover $P$. aeruginosa in the initial empirical treatment in these patients with more serious pictures who require hospitalization and with baseline disease.

Our study communicates results that reach those of favorable clinical evolution in $97.5 \%$ of the cases with the use of piperacillin-tazobactam in single drug therapy with a very limited incidence of adverse effects (6.3\% of the patients), and that did not make it necessary to discontinue the drug in any case. This manifests the usefulness of the antibiotic treatment in single drug therapy in this type of infection, as has been demonstrated in another type of infectious diseases. The economic savings that this type of antibiotic treatment means should also be considered. ${ }^{27}$

\section{Conclusions}

In conclusion, the clinical and microbiological efficacy together with the limited adverse effects presented make piperacillin-tazobactam an effective alternative in the management of this type of infections. 
14. Johnson BS. Principles and practice of antibiotic therapy. Infect Dis Clin North Am 1999;13:851-70, vi-vii.

15. Hill MK, Sanders CV. Principles of antimicrobial therapy for head and neck infections. Infect Dis Clin North Am 1988;2(1):57-83.

16. Peterson LJ. Contemporary management of deep infections of the neck. J Oral Maxillofac Surg 1993;51:226-31.

17. Lewis MA, Parkhurst CL, Douglas CW, Martin MV, Absi EG, Bishop $\mathrm{PA}$, et al. Prevalence of penicillin resistant bacteria in acute suppurative oral infection. J Antimicrob Chemother 1995;35:785-91.

18. Heimdahl A, von Konow L, Nord CE. Isolation of beta-lactamaseproducing Bacteroides strains associated with clinical failures with penicillin treatment of human orofacial infections. Arch Oral Biol 1980;25: 689-92.

19. Hood FJ. The place of metronidazole in the treatment of acute orofacial infection. J Antimicrob Chemother 1978;4 Suppl C:71-3.

20. Ingham HR, Hood FJ, Bradnum P, Tharagonnet D, Selkon JB. Metronidazole compared with penicillin in the treatment of acute dental infections. Br J Oral Surg 1977; 14:264-9.

21. García M, Rodríguez J, M. B. Escherichia coli resistentes a amoxicilina clavulánico en infecciones del tracto urinario. Rev Esp Quimioterap 1996;9 (Supl.4):192.
22. Goldstein FW. Antibiotic susceptibility of bacterial strains isolated from patients with community-acquired urinary tract infections in France. Multicentre Study Group. European Journal of Clinical Microbiology and Infectious Diseases 2000;19:112-7.

23. Giner S, Canós M, Rodilla F, Ferrer C. Valoración de los inhibidores de las betalactamasas. Farm Hosp 1996;20:225-35.

24. Kuck N. In vitro and In vivo efficacy of YRT-830H and piperacillin combinations versus beta-lactamase producing bacteria. J. Chemother 1989;1:155-61.

25. Kuck NA, Jacobus NV, Petersen PJ, Weiss WJ, Testa RT. Comparative in vitro and in vivo activities of piperacillin combined with the beta-lactamase inhibitors tazobactam, clavulanic acid, and sulbactam. Antimicrobial Agents and Chemotherapy 1989;33:1964-9.

26. Brook I, Frazier EH, Gher ME. Aerobic and anaerobic microbiology of periapical abscess. Oral Microbiol Immunol 1991;6: 123-5.

27. Torres Garcia A, Rubio Terres C, Alvarez Bravo J. Análisis farmacoeconómico de minimización de costes del tratamiento de las infecciones intraabdominales con piperacilina-tazobactam en comparación con cefotaxima más metronidazol. Cirugía Española 1999;65: 28-34. 


\title{
Eficacia de la monoterapia con Piperacilina-tazobactam en infecciones del área maxilofacial
}

\author{
Efficacy of single drug therapy with piperacillin-tazobactam in infections of the maxillofacial area
}

Cualquiera que sea la especialidad quirúrgica, la infección constituye siempre una de las complicaciones más temidas para el cirujano. En el área de la Cirugía Maxilofacial ello no es menos cierto y son bien conocidas las gravísimas complicaciones - derivadas de la compleja anatomía cérvico-facial- a las que estas infecciones pueden dar lugar. ${ }^{1}$

En el proceso de desarrollo y registro de los nuevos antibióticos no suele incluirse la experimentación en las infecciones del área maxilofacial. Los más modernos antibióticos suelen tardar en incorporarse al tratamiento de estas infecciones $y$, cuando lo hacen, generalmente es la analogía con otro tipo de infecciones polimicrobianas la que determina su incorporación. Por este motivo el estudio publicado en este número de la revista, ${ }^{2}$ que aporta la experiencia con el empleo de piperacilina-tazobactam en las infecciones del área maxilofacial, es bien recibido y constituye un ejemplo de lo comentado.

Piperacilina-tazobactam es la asociación de una penicilina con actividad antipseudomónica con un inhibidor de beta-lactamasas que amplía el espectro frente a enterobacterias y estafilococos, al tiempo que proporciona una amplísima cobertura frente a bacterias anaerobias. Su eficacia ha sido bien documentada en pacientes neutropénicos así como en infecciones respiratorias, de la piel y tejidos blandos e intraabdominales. ${ }^{3}$

Es cierto que la mayor parte de las bacterias que forman parte de la flora nativa "normal" de la cavidad oral se muestran habitualmente sensibles a la penicilina y, por ello, no es la resistencia a los antibióticos uno de los problemas esenciales que se invoca en las infecciones maxilofaciales. Sin embargo, antes o después, el cirujano maxilofacial se enfrenta a patógenos resistentes, bien sea por la aparición de infecciones postquirúrgicas nosocomiales, bien por la atención a pacientes debilitados, que portan entre su flora oral patógenos como enterobacterias resistentes o Pseudomonas aeruginosa. La flora oral está constituida por un conjunto de múltiples especies en un delicado equilibrio. Las enfermedades debilitantes, situaciones de estrés sistémico y, sobre todo, el tratamiento antibiótico, condicionan la alteración de esta compleja microflora. ${ }^{4}$ Las infecciones que se producen en ese contexto pueden estar protagonizadas, entonces, por enterobacterias o Gram-negativos no fermentadores, resistentes a los antibióticos generalmente empleados para tratar las infecciones orofaciales.

Varios trabajos han demostrado que, en infecciones graves como bacteriemias, ${ }^{5}$ y neumonías nosocomiales, ${ }^{6}$ la elección inadecuada del antibiótico (entendiendo por tal la elección de un tratamiento empírico que no cubría al patógeno finalmente aislado) condiciona una mayor mortalidad de manera independiente de otros factores. Repetidamente, además, estos estudios muestran que la corrección tras la recepción del informe microbiológico sirve ya de poco. Nada hace pensar que,
Whatever the surgical speciality, infection is always one of the complications most feared by the surgeon. In the Maxillofacial Surgery area, this is no less true and its extremely serious complications, derived from the cervico-facial anatomy complex, to which these infections may give rise are well known. ${ }^{1}$

In the development and registry process of new antibiotics, experiments in maxillofacial area infections are not generally included. The most modern antibiotics are generally late in incorporating these infections into the treatment and when they do so, it is generally the analogue with another type of polymicrobian infections that determines its incorporation. Thus, the study published in this number of the journal, ${ }^{2}$ that provides experience with the use of piperacillintazobactam in maxillofacial area infections, is well received and constitutes an example of that mentioned.

Piperacillin-tazobactam is the association of a penicillin with antipseudomonal activity with a beta-lactamase inhibitor that extends the spectrum against enterobacterias and staphylococci while providing very wide coverage against anaerobic bacterias. Its efficacy has been documented in neutropenic patients as well as in respiratory, skin, soft tissue and intraabdominal infections. ${ }^{3}$

It is true that most of the bacteria that form a part of the "normal" native flora of the oral cavity are usually sensitive to penicillin and thus, resistance to antibiotics is not one of the essential problems invoked in maxillofacial infections. However, sooner or later, the maxillofacial surgeon faces resistant pathogens, either due to the appearance of nosocomial post-surgical infections or to care of weakened patients who have pathogens such as resistant enterobacteria or Pseudomonas aeruginosa among their oral flora. The oral flora is made up of a combination of multiple species in delicate equilibrium. Weakening diseases, systemic stress conditions and, above all, antibiotic treatment, condition the alteration of this microflora complex. ${ }^{4}$ Infections that are produced in this context may be protagonized, therefore, by enterobacteria or non-fermenting gram-negative bacteria, resistant to the antibiotics generally used to treat orofacial infections.

Several studies have demonstrated that, in serious infections with bacteriemias ${ }^{5}$ and nosocomial pneumonias, ${ }^{6}$ inadequate choice of antibiotic (understood as such the choice of an empiric treatment that does not cover the finally iso- 
cuando la infección es grave, no ocurra lo mismo en las infecciones del área maxilofacial. Así, en determinados contextos, la elección del tratamiento antibiótico empírico para infecciones orofaciales deberá ser de amplio espectro. El estudio de Delgado Sánchez y cols., ${ }^{2}$ permite confirmar a piperacilina-tazobactam como una opción adecuada para el tratamiento empírico de las infecciones graves del área maxilofacial en las que se sospeche la participación de enterobacterias o Pseudomonas aeruginosa.

En la anticipación de los patógenos más probables y sus resistencias potenciales, tres consideraciones resultan esenciales: la patología de base, el entorno epidemiológico de resistencias y el antecedente de administración previa de antibióticos. De este modo, la elección del tratamiento de la misma entidad anatomoclínica podrá variar considerablemente dependiendo del contexto del paciente en el que tenga lugar.

Pero la administración óptima del tratamiento antibiótico va más allá de la simple elección de un fármaco activo frente a los patógenos causantes de la infección. Hoy hablamos cada vez más de "optimización" del tratamiento antibiótico. ${ }^{7}$ Bajo este término englobamos aquellas estrategias que permitan obtener el máximo beneficio de los antibióticos al tiempo que se minimizan sus efectos adversos, entre los cuales se incluye la selección de bacterias resistentes. Entre estas estrategias se incluyen la dosificación de acuerdo a criterios farmacodinámicos, 8 la reducción en la duración del tratamiento, ${ }^{9}$ o la terapia secuencial intravenosa-oral. ${ }^{10}$ La breve duración del tratamiento intravenoso comunicada en el estudio presentado en este número es también un buen ejemplo de una administración individualizada del tratamiento antibiótico, terreno sobre el cual existe una considerable necesidad de investigación.

El tratamiento antibiótico es, por tanto, un asunto mucho más dinámico y complejo de lo que solemos encontrar en las tablas que aparecen en la mayor parte de los capítulos de los libros o en las revisiones y requiere mucha más individualización de lo que suele creerse. Estrictamente, no deberíamos plantearnos los tratamientos antibióticos, de forma semiautomática, en función, sin más, de un territorio anatómiCo, sino más bien responder racionalmente a una serie de preguntas, sistemáticamente planteadas. Entre ellas incluiríamos la anticipación de los patógenos más probablemente implicados, la selección del antibiótico en función de la sospecha y de las características del huésped, la pertinencia de la terapia combinada, la elección optimizada de la dosificación, la selección racional de la vía de administración, la duración necesaria del tratamiento y la adecuación a los resultados microbiológicos correctamente interpretados.

La prescripción basada en la respuesta correcta a cada una de estas preguntas constituirá la mejor política de antibióticos y proporcionará a los pacientes el máximo beneficio de estos excelentes fármacos, amenazados por la emergencia de nuevas resistencias originadas por su empleo, no siempre cuidadoso.

J. Cobo Reinoso

Servicio de Enfermedades Infecciosas Hospital Ramón y Cajal. Madrid, España lated pathogen) conditions greater mortality independently of other factors. Repeatedly, in addition, these studies show that correction after receiving the microbiological report is of little use. There is nothing that leads us to think that when the infection is serious, the same does not occur in maxillofacial area infections. Thus, in certain contexts, the choice of empiric antibiotic treatment for orofacial infections should be wide spectrum. The Delgado Sánchez et al. ${ }^{2}$ study makes it possible to verify piperacillin-tazobactam as an adequate option for the empiric treatment of serious maxillofacial area infections in which the participation of enterobacteria or Pseudomonas aeruginosa is suspected.

In anticipation of the most likely pathogens and their potential resistances, three considerations are essential: baseline pathology, epidemiological setting of resistances and background of previous administration of antibiotics. In this way, choice of treatment of the same anatomical-clinical entity could vary considerably, depending on the patient context in which it takes place.

However, the optimum administration of antibiotic treatment goes beyond the simple choice of a drug active against infection causing pathogens. We now increasingly speak about "optimization" of the antibiotic treatment. ${ }^{7}$ With this term, we include those strategies that make it possible to obtain the maximum benefit of the antibiotics while minimizing their adverse effects, among which the selection of resistant bacteria is included. Among these strategies, dosing according to pharmacodynamic criteria, ${ }^{8}$ reduction in treatment duration ${ }^{9}$ or intravenous-oral sequential thera$p y^{10}$ are included. The short duration of the intravenous treatment reported in the study presented in this number is also a good example of individualized administration of the antibiotic treatment, an area in which there is considerable need for investigation.

The antibiotic treatment is, thus, a much more dynamic and complex matter then that which we generally find in the tables appearing in most of the book chapters or reviews and requires much more individualization than generally believed. Strictly, we should not establish antibiotic treatments semiautomatically based on no more than an anatomic territory. It is better to rationally respond to a series of systematically posed questions. These include the anticipation of the most likely involved pathogens, the selection of the antibiotic based on suspicion and the characteristics of the host, relevance of the combined therapy, optimized choice of dosage, rational selection of the administration route, necessary treatment duration and adaptation to the correctly interpreted microbiological results.

Prescription based on the correct response to each one of these questions would be the best antibiotic policy and would provide the patients the maximum benefit of these excellent drugs, threatened by the emergence of new resistances originated by their not always careful use. 


\section{Bibliografía}

1. J.D. Wagner. Odontogenic surgical infections. En Surgical Infections. D. E. Fry. ed. Little Brown Company. Boston 1995; Chap. 51. Pgs: 487-94.

2. Flynn TR. The swollen face. Severe odontogenic infections. Emerg Med Clin North Am 2000;18:481-519.

3. Perry CM, Markham A. Piperacillin/tazobactam: an updated review of its use in the treatment of bacterial infections. Drugs. 1999;57: 80543.

4. WG Johanson. Impaired colonization defence of the oropharynx. En: HKFvan Saene, CP Stoutenbeek, P Lawin and I McA Ledingham. eds. Update in intensive care and emergency medicine. Infection control by selective decontamination. New York. Springer-Velag, 1989;2833.

5. Valles J, Rello J, Ochagavia A, Garnacho J, Alcala MA. Community- acquired bloodstream infection in critically ill adult patients impact of shock and inappropriate antibiotic therapy on survival. Chest. 2003 123:1615-24.

6. Luna CM, Vujacich P, Niederman MS, Vay C, Gherardi C, Matera J, Jolly EC. Impact of BAL data on the therapy and outcome of ventilator-associated pneumonia. Chest. 1997;111:676-85.

7. Polk R. Optimal use of modern antibiotics. Clin Infect Dis 1999;29:2647.

8. Levison ME. Pharmacodynamics of antibacterial drugs. Infect Dis Clin North Am. 2000;14:281-91.

9. Chastre J, Wolff M, Fagon JY, Chevret S, Thomas F, Wermert D, y cols. Comparison of 8 vs 15 days of antibiotic therapy for ventilator-associated pneumonia in adults: a randomized trial. JAMA. 2003;290: 258898.

10. Cunha BA. Intravenous-to-oral antibiotic switch therapy. A cost-effective approach. Postgrad Med. 1997;101:111-2. 